Volume 5, Issue 1 (Winter 2013)

\title{
A needlework by Philips van den Bossche (fl. 1604-1615)
}

Matthijs Ilsink, Monica Marchesi

Recommended Citation:

Matthijs Ilsink, Monica Marchesi, "A Needlework by Philips van den Bossche (fl. 1604-1615)," JHNA 5:1 (Winter 2013), DOI: 10.5092/jhna.2013.5.1.2 Available at https://jhna.org/articles/needlework-philips-van-den-bossche-fl-1604-1615/

Published by Historians of Netherlandish Art: https://hnanews.org/

Republication Guidelines: https://jhna.org/republication-guidelines/

Notes: This PDF is provided for reference purposes only and may not contain all the functionality or features of the original, online publication. This is a revised PDF that may contain different page numbers from the previous version. Use electronic searching to locate passages. This PDF provides paragraph numbers as well as page numbers for citation purposes.

ISSN: 1949-9833 


\title{
A NEEDLEWORK BY PHILIPS VAN DEN BOSSCHE (fl. 1604-1615)
}

\author{
Matthijs Ilsink, Monica Marchesi
}

Philips van den Bossche (fl. 1604-1615) was the court embroiderer to emperor Rudolf II in Prague. After the death of Rudolf in 1612 Van den Bossche is documented in Augsburg. Apart from a dozen drawings for various purposes, no needleworks have been known to survive. Published here is the first securely attributed needlework to Van den Bossche, a rare example of a work sewn in silk. 10.5092/jhna.2013.5.1.2

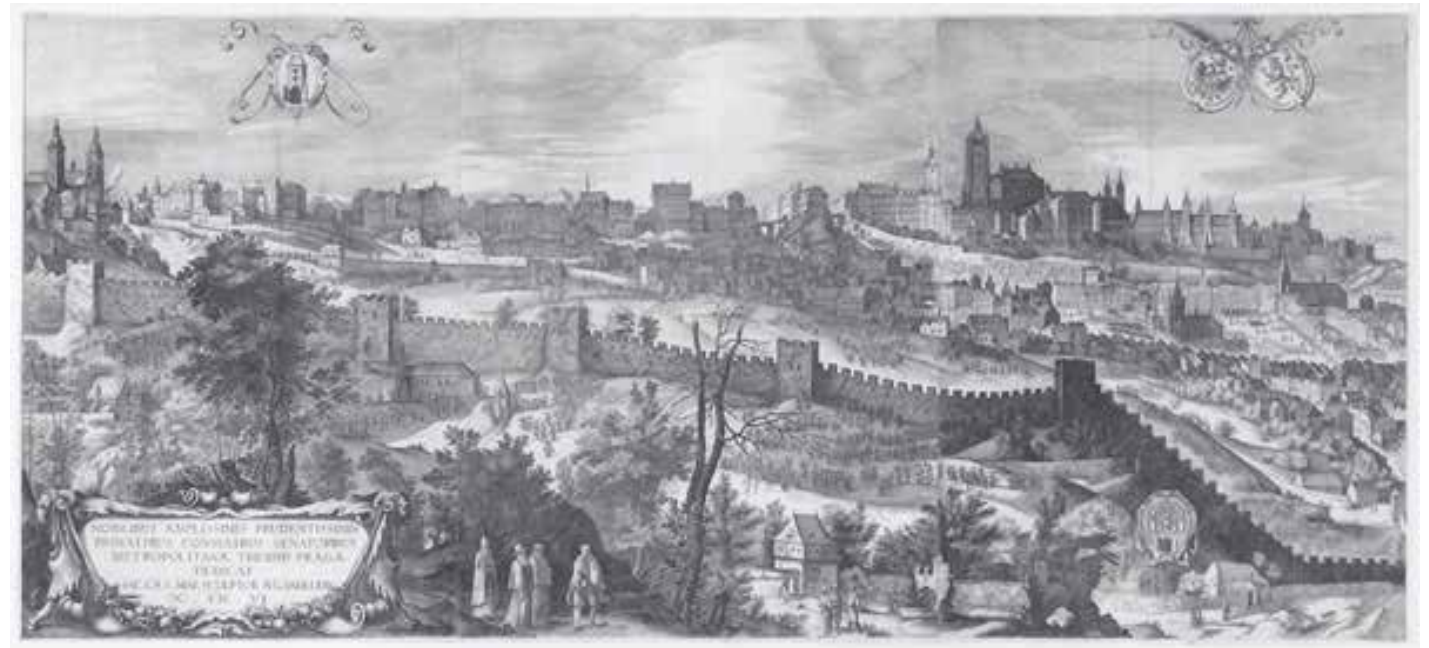

Fig. 1 Hans Wechter the Elder, after a design by Philips van den Bossche, View of Prague, 1606, etching, each of the nine sheets measures $473 \times 355 \mathrm{~mm}$.

ne of the many artists active in the entourage of Rudolf II (1552-1612), king of Hungary and Bohemia and emperor of the Holy Roman Empire, was Philips van den Bossche (fl. 1604-1615). ${ }^{1}$ Van den Bossche was active as Camer-Seidensticker (court embroiderer).

Nowadays he is best known as the designer of a well-known panoramic View of Prague of 1606 (fig. 1). ${ }^{2}$ The View of Prague comprises nine separate plates etched by Hans Wechter the Elder (ca. 1550-after 1606), which when combined total more than three meters in length. The print was published by Aegidius Sadeler the Younger (ca. 1570-1629) in 1606. Over a hundred places in the city are keyed by number, all of them described in a separately printed legend. The image as a 
whole gives a beautiful impression of both the size and splendor of the city of Prague during the reign of Emperor Rudolf II. Of its design only a fragment survives and is kept in the collection of prints and drawings at the University of Göttingen (fig. 2).

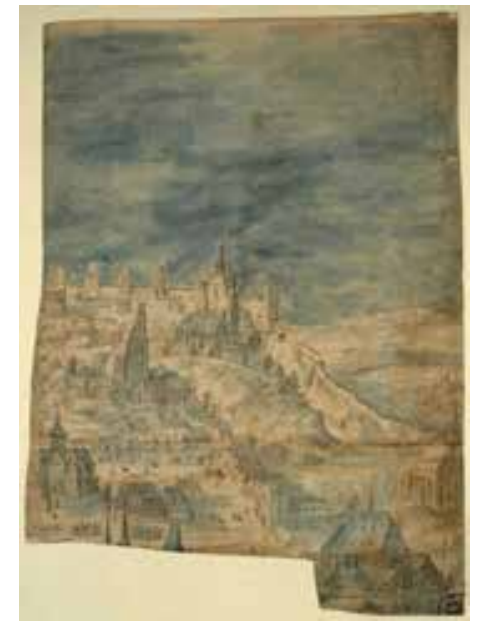

Fig. 2 Philips van den Bossche, Fragment of a Design for a "View of Prague," ca. 1605, pen and brown ink, with blue wash, the contours of two buildings on the recto traced in black chalk on the verso, irregularly trimmed on bottom and both sides, $324 \times 232 \mathrm{~mm}$ (at widest points). Göttingen, Kunstsammlung der Universität, Graphische Sammlung, inv. no. H. 355.

Although he was active as an embroiderer in the service of the emperor, Van den Bossche is primarily known as the draftsman of about a dozen drawings. ${ }^{3} \mathrm{He}$ worked in a style similar to that of such artists as Paulus van Vianen (ca. 1570-1613), Roelandt Savery (1576-1639), and Pieter Stevens (ca. 1567-after 1624), all of whom were active at the Prague court. Van den Bossche's own way of working is characterized by a strong linearity and short strokes of the pen (fig. 3). The short, often straight lines give these drawings a somewhat flat appearance. One can imagine that this drawing style was prompted by Van den Bossche's profession as an embroiderer, echoing the short, straight stitches of the silk threads that make up the sewn paintings he was producing.

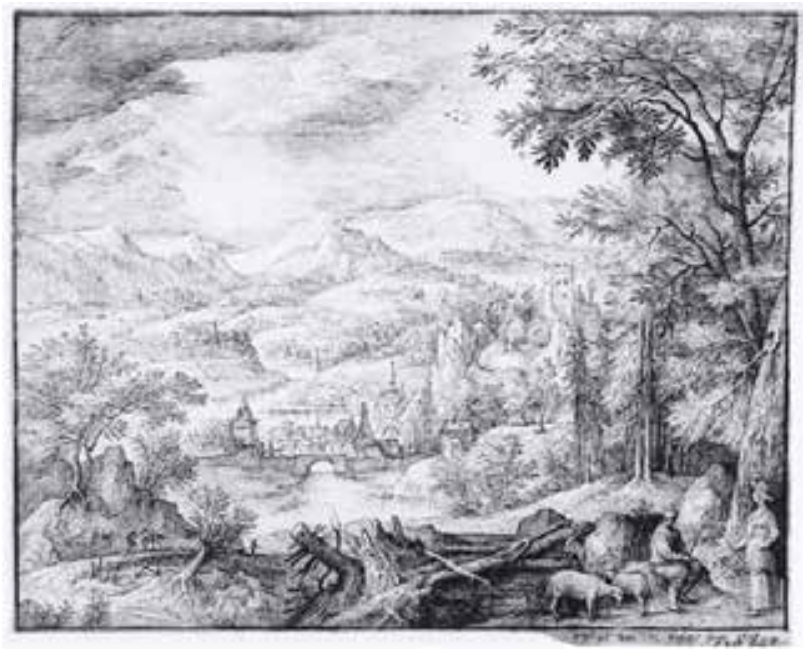

Fig. 3 Philips van den Bossche, Landscape with a Shepherd and the Sun Breaking Through, 1615, pen and dark gray ink on vellum, 146 x $184 \mathrm{~mm}$. Signed and dated at lower right, in black ink, philips van den bosche fecit 1615. Brussels, Bibliothèque Royale Albert ler, inv. no. F 20225, fo.

Both thematically and compositionally, the drawings fit perfectly with the fashion of the time for wooded and panoramic landscapes in the tradition of Pieter Bruegel the Elder. In one or two instances we can sense that Van den Bossche had knowledge of drawings by fellow artists Stevens and Savery (fig. 4). The many prints after these artists' designs by such engravers as the Sadelers and Isaac Maior probably also played an important role in the conception of his drawings, both 
compositionally and stylistically.

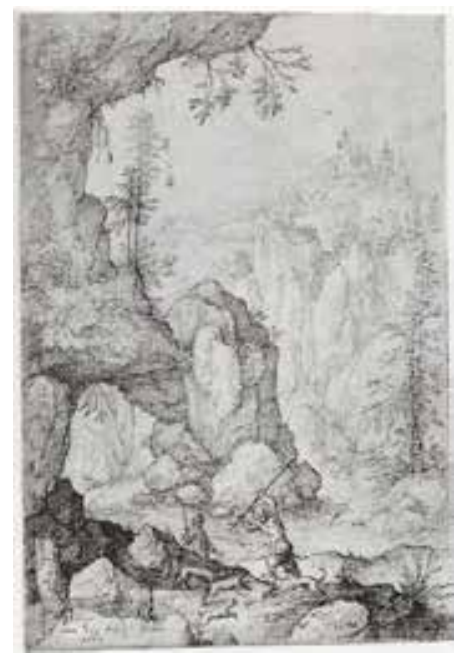

Fig. 4 Philips van den Bossche, Mountain Landscape with a Hunting Scene, 1609, pen and brown ink, 134 × $90 \mathrm{~mm}$. Signed and dated at lower left, Philips / van den bosche fecit / 1609. Berlin, Staatliche Museen zu Berlin, Kupferstichkabinett, inv. no. KdZ 12408.

There is no documentary evidence of Philips Van den Bossche's activity before 1604. It is not known where or when he was born or died. He must, however, have come from the Low Countries. As his name indicates, he was probably a native of 's-Hertogenbosch in the northern part of the duchy of Brabant. Like other contemporary Flemish artists, he may have gone south to one of the more important artistic centers, such as Brussels, Antwerp, or Mechelen. After training in the tradition of such landscapists as Hans Bol (1534-1593) and Gillis van Coninxloo III (1544-1607), Philips must have traveled to central Europe instead of the Northern Netherlands (as did Bol and Coninxloo). As is well known, Hapsburg and other sources of patronage in such central European cities as Augsburg, Munich, Salzburg, and Prague attracted many Netherlandish artists around 1600. Van den Bossche is first documented in Prague between 1604 and 1612, working as the imperial embroiderer. After that, he is known to have worked in Augsburg in 1615.

The first mention of Van den Bossche is found in the accounts of the imperial court at Prague. As was noted by the scholar Heinrich Modern, the artist entered the service of Rudolf II on July 1 , 1604, as imperial Camer-Seidensticker (court embroiderer). ${ }^{5}$ His salary was set at 30 guilders per month. Apparently the artist had just arrived in Prague, since he received another 150 guilders for moving expenses on September 13, 1604. This rate was generous, as was his monthly allowance -which was more than practically any other artist received at the Rudolphine court. ${ }^{6}$ The accounts of the following years, however, indicate that Philips never received the total annual salary of 360 guilders. He earned 240 guilders in 1605, 180 guilders in 1606, and 420 guilders in 1607. (The significantly larger amount in the last year may have had something to do with his designs for the View of Prague of 1606.) In 1608 he received 180 guilders, in 1609120 guilders. The next two years he was paid nothing. The last mention of him occurs in 1612, when he earned 120 guilders. In late January of that year he received another 30 guilders and 42 crowns for "expenses." This last amount may be connected with the death of Rudolf II on January 20, 1612, and the period of his lying-in-state before his burial on February 5. 
Van den Bossche also embroidered book covers and flower still lifes. ${ }^{7}$ From the same inventory we learn that Philips had a daughter, Elisabeth, who, along with her husband, H. Cappelman, was active in the same profession. Both are listed with an embroidered flower still life. ${ }^{8}$ Although a dozen landscape drawings by Philips van den Bossche survive today, as well as the large panoramic view of the city of Prague printed after his design, scholars have not been able to make any secure attributions of embroideries to this artist.

In the past, only one surviving needlework has been attributed to Van den Bossche. The British Museum preserves a small tabernacle with a colored wax relief of a Pietà (fig. 5). ${ }^{9}$ It is a three-dimensional reproduction of a well-known painting by Willem Key (1516-1568) in Munich. ${ }^{10}$ The Madonna is dressed with cloth and the hair of Christ has been pasted onto the wax. The background of the relief is particularly interesting, as it consists of an embroidered landscape with figures, a castle, and the hill of Golgotha. The handling of the landscape and the figures (the latter do not appear in the painting by Key) is very similar to that of the extant drawings by Van den Bossche. This led Eliška Fucíková to conclude that the needlework in this tabernacle must be the work of Rudolf's court embroiderer. ${ }^{11}$ In the inventory of Rudolf's Kunstkammer, about fifty of these wax reliefs are mentioned..$^{12}$ None of these, however, can be identified as the London piece. Although an attribution to Van den Bossche is tempting, the evidence is inconclusive.

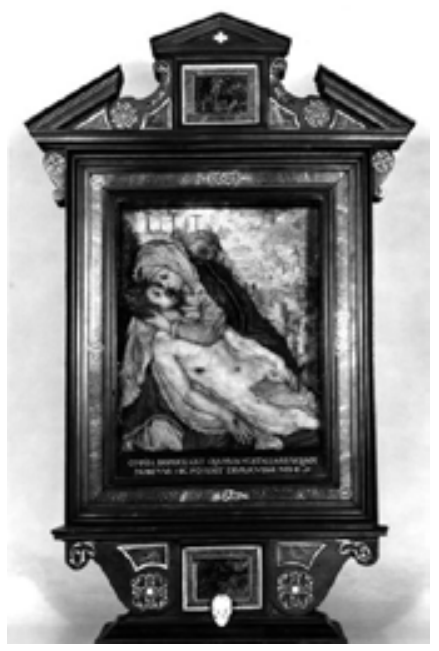

Fig. 5 Attributed to Philips van den Bossche, Pietà, tabernacle with colored wax relief and embroidered background, ebony case, wax, cloth, silk embroidery, brass ornamentation, lapis lazuli (painted with oils), and ivory, $62.3 \times 33.3 \times 13 \mathrm{~cm}$. London, British Museum, inv. no. 1852-3-27.12.

A far better candidate for attribution to Van den Bossche is a small needlework $(31.7 \times 28.2 \mathrm{~cm})$ in a Dutch private collection that depicts a wooded landscape with the Rest on the Flight into Egypt (fig. 6). This extremely rare and interesting needlework can be attributed to Phillips van den Bossche on the basis of both style and a contemporary letter pasted onto the back of the work. Built up with various kinds of threads, the scene is embroidered on a linen support. Different dyes have been used to color the silk threads. Silver and gold are the main constituents of the different metallic threads. The XRF and SEM analyses carried out during an investigation of the work confirm what can be suspected through examination with the naked eye, namely that Van den Bossche made extensively use of metallic threads throughout the needlework. ${ }^{13}$ Gilt silver threads of different thickness and of various manufacture have been used in different areas of the piece: in the foliage of the tree in the middle foreground a thread with a golden tone is much employed to enhance the flickering of the leaves while in the ruined stable on the right, in the 
part that should indicate the remains of a fachwerk (half-timbered) structure, an entwined thread with a dark, silver-like color can be discerned (fig. 7 ). ${ }^{14}$ The rest of the needlework uses colored silk threads to create a vibrant image of Mary, Christ, and Joseph (fig. 8). Philips Van den Bossche used different stitches to produce this precious little work, which is so complex and detailed it might be termed a "needle painting." 15 The sky, the background, and the figures were formed using a split stitch to suggest a smooth progression of the colors. The foliage of the trees and the grass are formed by stem stitches. The stable is formed by a layer of silk strand in which threads are applied on top of the structure and the stitches are alternatively sewn to suggest a brick pattern. The metallic threads are fastened to the needlework by couching stitches. By using this particular stitch it was possible to create a sparkly surface and add depth. ${ }^{16}$

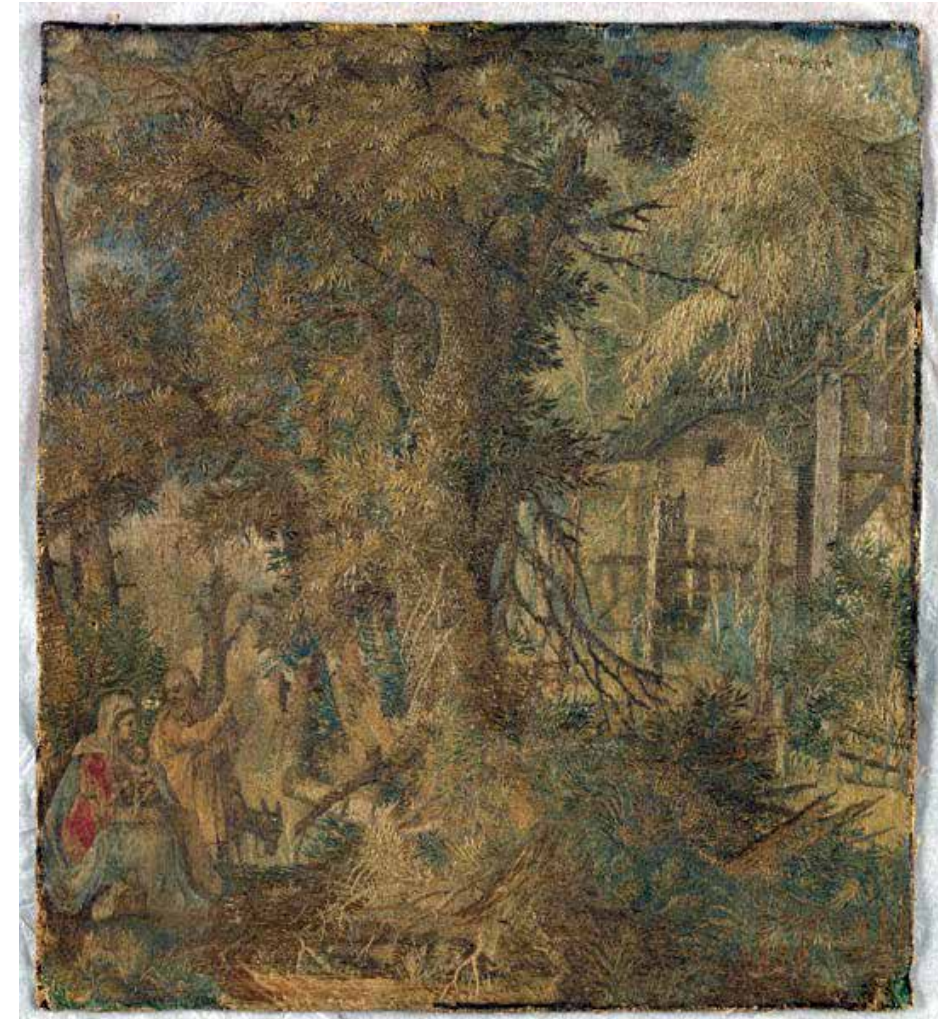

Fig. 6 Philips van den Bossche, Wooded Landscape with the Rest on the Flight into Egypt, ca. 1610, needlework, $31.7 \times 28.2$ $\mathrm{cm}$. Private collection, The Netherlands.

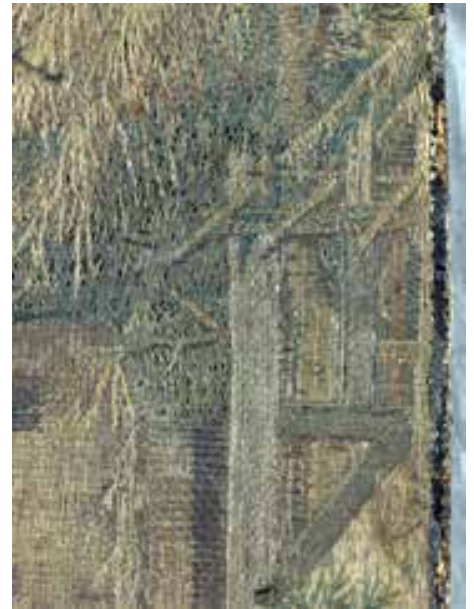

Fig. 7 Detail of fig. 6.

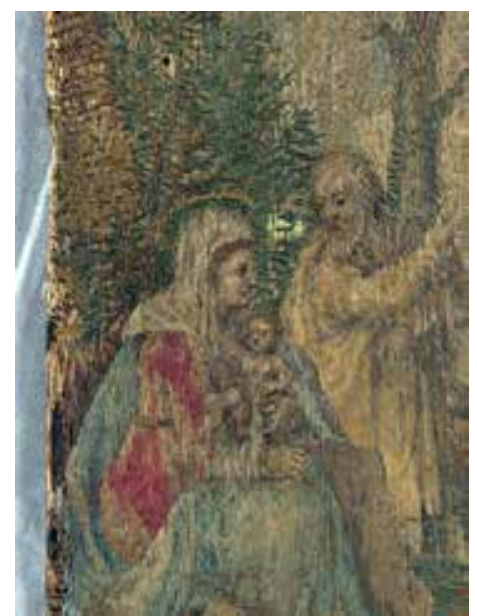

Fig. 8 Detail of fig. 6 .

9 The scene, with its dense forest and relatively small figures stressing the majesty and force of nature, can be compared to many examples of the landscape art of central Europe around 1600, especially that of (prints after) Roelandt Savery. A drawing in the Museum Boijmans Van Beuningen that can be attributed to Philips van den Bossche (with some reservation) is equally comparable (fig. 9). There we see a similar structuring of the composition, with the figures of Tobias and the angel pushed into the lower right corner. The way Van den Bossche rendered the trees and their foliage in this needlework, with short straight lines, is something also seen in the drawing from Brussels (fig. 3). 


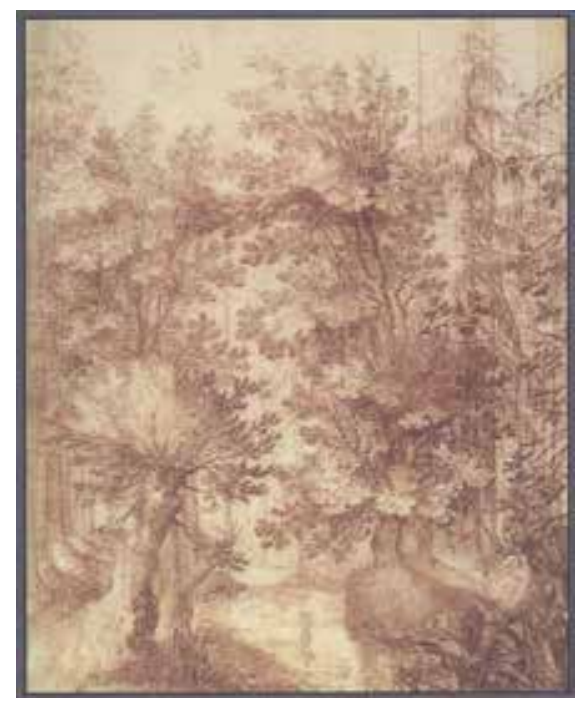

Fig. 9 Philips van den Bossche (?), Forest Landscape with Tobias and the Angel, pen and dark brown (iron gall) ink, framing line in black ink, 241 x $193 \mathrm{~mm}$. Rotterdam, Museum Boijmans Van Beuningen, inv. no. N 52.

10 A thin embroidered black line, much of which is lost on the left side of the work, frames the whole. The object is in fairly good condition, although the colors and the glitter of the gold are much reduced by a rather thick layer of discolored varnish. ${ }^{17}$

11 The Landscape with the Rest on the Flight into Egypt was at some time in the past glued on a wooden backing. The exact time and the reason for this treatment remains unknown. However, in recent years partial damage to the backing posed a possible threat of damage to the verso of the needlework itself. For this reason it was decided to remove the backing.

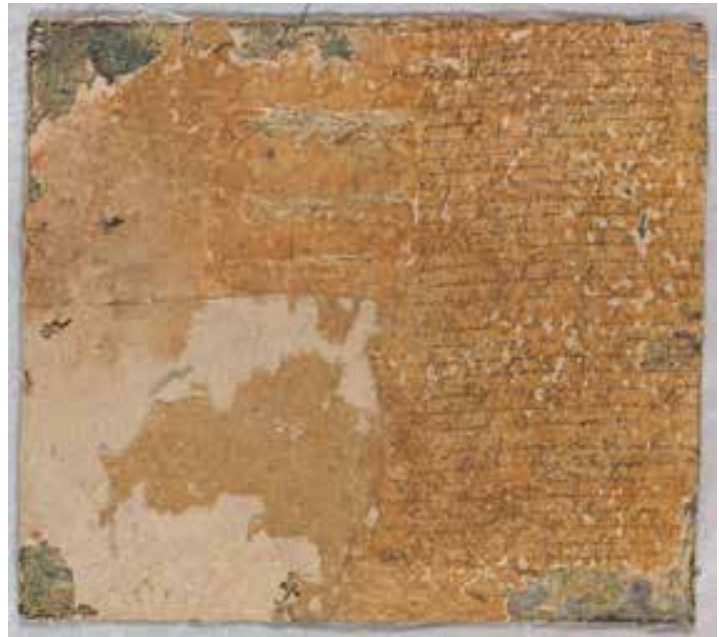

Fig. 10 Back of Wooded Landscape with the Rest on the Flight into Egypt (fig. 6).

12 When this was done, a paper document, which had been pasted onto the back of the needlework, was revealed underneath (fig. 10). ${ }^{18}$ Although the handwriting of the document is quite legible, there are several lacunas in the text -- a fragment of a letter the beginning and ending of which are missing. The conclusion of the letter was perhaps written on the verso of the paper or even on another sheet, since the text stops abruptly. Around 2 centimeters of blank paper remain at the bottom. On the right, approximately 1 to 1.5 centimeters of the text are missing. Nevertheless, the content of the letter is quite clear: a mandate for Philips van den Bossche to represent the scribe at the chancellery of Braunschweig in Wolfenbüttel (see the transcription in the appendix). ${ }^{19}$ The author of the letter was in the service of Rudolf II in Prague and had been charged with a capital 
offence. These charges had been pressed on the first of August 1608. The accused states in this document that he cannot leave Prague due to his numerous activities at the imperial court. Therefore he sends and empowers Philips van den Bossche to represent him in Wolfenbüttel (fig. 11). ${ }^{20}$ The letter seems to have been written shortly after 1608 , since the word abgewichenen is used in connection with this date.

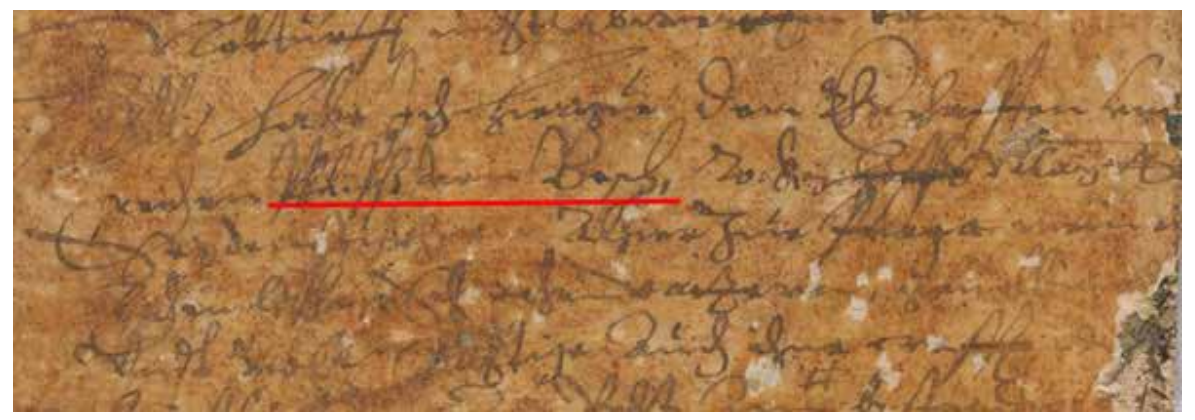

Fig. 11 Detail of fig. 10.

13 Although the letter and the needlework are not necessarily connected, it hardly seems possible that a written document which must have been in the possession of the imperial embroiderer Philips van den Bossche could coincidentally appear on the back of a needlework likely dating from the first decade of the seventeenth century. Moreover, the style and composition are related to the extant drawings by Van den Bossche, as well as to the works of such artists as Pieter Stevens, Paulus van Vianen, and Roelandt Savery. Thus, we assume that Philips van den Bossche remained in the possession of the letter and used it later to reinforce one of his embroideries. ${ }^{21}$ Supposedly he did this while he was still in the service of Rudolf II in Prague and before he moved to Augsburg after Rudolf's death in January 1612. The 1606-11 inventory of the Rudolfine Kunstkammer mentioned above includes a small scene just like the needlework published here: "1 klein täfelin vom Philip vom Bösch ob: tapezier, ist unser fraw und Joseph in einer landtschafft, ligt in einem fütterlin von lindenholtz, von seiden mit der nadel. ${ }^{22}$ One wonders if this could be the work published here. In any event, we should consider the needlework under discussion as the first needle painting that can be securely attributed to Philips van den Bossche. This is an extraordinary case. Embroidered paintings like this are extremely rare, and in this instance, we are even able to pinpoint its maker.

\section{Appendix ${ }^{23}$}

1. [ö]ffentlichen crafft die[ $[\beta$ es br] ieffs ......

2. Demnach Arn[ol]d $[\mathrm{t}][\mathrm{K}]$ empes $]$......

3. ... Furstl(ichen) Braunschweygischen $\mathrm{C}[\mathrm{a}]$ ncelleye [zue]

4. Wolffenbüttel gegen mir ...

5. unbegrundte Clagschrifft unlengst den 1[.] August

6. abgewichenen 1608. Jahrs [verm] essentlich (?) ... duc ...

7. eingeleget. Darauffer nun mit ...

8. gegenbericht, nit allein wegen gedachten ...

9. unfuegsamer ... undt unerwaßlichen Vor ...

10. sondern auch furnemlich sei[ner] g[e]gen mir ... 
11. ter vermeintlichen Clagschrifft, ...

12. freventlicher weyßevomirter

13. verl[e] umdungen, sa ... falscherdi...

14. unbillicher bezuchtigung ettlicher ... straffli[cher Ca-]

15. pital delicten, deme muetwill[ig]en clag...

16. begegnen, die notturfft sonderlichen $\mathrm{z}[\mathrm{ue}]$...

17. meiner wolherbrachten ehren, auch guette (?) ...

18. unndt geruchts halben, erfoderen ...

19. Und dieweile ich aber außverhinderung [durch?]

20. meiner zue Prage an [Key(serlicher)] May(es)t(ät) h[o]ff

21. obliegender vielfältig überhauffen ...

22. Sachen, bey hochgedachten Furstl(lichen) Braunsch[weygichen]

23. Cancelleye mit erbringung meines gegen ...

24. unndt sonsten verhandlung an derer gebuhren ...

25. Noturfft nicht abwerffen kann,

26. Alls habe ich hierzu den ehrenhafften und ...

27. reichen Philipßvon Bosch, I(hr)o Key(serlicher) [hochgedachter] May(esta)t

28. Seydenstickher alhier zue Praga meine ...

29. lichen (?) lassen, Sch... vatteren (?) gevollma[chtigt]

30. undt voll[ma]chtige auch ihne crafft $\mathrm{d}[\mathrm{ie} \beta \mathrm{es}]$...

31. brieffs [wie er] zue Recht am bestendeg(?) ...

32. ken undt moge, Dergestallt ...

33. undt stadt (?) ..., doch außerhalb ...

\section{Acknowledgments}

During the preparation of this article we received the help of several people whom we would like to thank here: Ebeltje Hartkamp-Jonxis (Amsterdam, Rijksmuseum), Emmy de Groot (Amsterdam, UVA), Ineke Joosten (Amersfoort, RCE), Suzan Meijer (Amsterdam, Rijksmuseum), Ulrich Schwarz (Wolfenbüttel, NLA-Staatsarchiv Wolfenbüttel), Bert Thissen (Kleve, Stadtarchiv), and Patricia Wardle (Amsterdam, Rijksmuseum).

Dr. Matthijs Ilsink is the coordinator of the Bosch Research and Conservation Project (BRCP). (See: http://www.bosch500.nl/nl/organisatie/bosch-research-and-conservation-project). He also teaches at Radboud University Nijmegen.

Monica Marchesi (MA) is a paper conservator and works in the conservation department of the Stedelijk Museum Amsterdam. As a researcher, since June 2012 she is participating in the NWO Science4Arts research project "Photographs and Preservation: How to Save Photographic Artwork for the Future?".

\section{List of Illustrations}


Fig. 1 Hans Wechter the Elder, after a design by Philips van den Bossche, View of Prague, 1606, etching, each of the nine sheets measures $473 \times 355 \mathrm{~mm}$.

Fig. 2 Philips van den Bossche, Fragment of a Design for a "View of Prague," ca. 1605, pen and brown ink, with blue wash, the contours of two buildings on the recto traced in black chalk on the verso, irregularly trimmed on bottom and both sides, $324 \times 232 \mathrm{~mm}$ (at widest points). Göttingen, Kunstsammlung der Universität, Graphische Sammlung, inv. no. H. 355.

Fig. 3 Philips van den Bossche, Landscape with a Shepherd and the Sun Breaking Through, 1615, pen and dark gray ink on vellum, $146 \times 184 \mathrm{~mm}$. Signed and dated at lower right, in black ink, philips van den bosche fecit 1615. Brussels, Bibliothèque Royale Albert Ier, inv. no. F 20225, fo.

Fig. 4 Philips van den Bossche, Mountain Landscape with a Hunting Scene, 1609, pen and brown ink, 134 x $90 \mathrm{~mm}$. Signed and dated at lower left, Philips / van den bosche fecit / 1609. Berlin, Staatliche Museen zu Berlin, Kupferstichkabinett, inv. no. KdZ 12408.

Fig. 5 Attributed to Philips van den Bossche, Pietà, tabernacle with colored wax relief and embroidered background, ebony case, wax, cloth, silk embroidery, brass ornamentation, lapis lazuli (painted with oils), and ivory, 62.3 x 33.3 x $13 \mathrm{~cm}$. London, British Museum, inv. no. 1852-327.12 .

Fig. 6 Philips van den Bossche, Wooded Landscape with the Rest on the Flight into Egypt, ca. 1610, needlework, 31.7 x $28.2 \mathrm{~cm}$. Private collection, The Netherlands.

Fig. 7 Detail of fig. 6.

Fig. 8 Detail of fig. 6

Fig. 9 Philips van den Bossche (?), Forest Landscape with Tobias and the Angel, pen and dark brown (iron gall) ink, framing line in black ink, 241 x 193 mm. Rotterdam, Museum Boijmans Van Beuningen, inv. no. N 52.

Fig. 10 Back of Wooded Landscape with the Rest on the Flight into Egypt (fig. 6).

Fig. 11 Detail of fig. 10.

${ }^{1}$ Heinrich Modern, "Eine Landschaft von Philip van den Bossche," Mitteilungen der Gesellschaft für Vervielfältigende Kunst 11 (1902); 50-53; Anna Rollová, "Philips van den Bossche,"in Saur Allgemeines Künstler-Lexikon, 13:203 (Munich and Leipzig, 1996); Matthijs Ilsink, "The Drawings of Philips van den Bossche," Master Drawings 44 (2006): 333-53, no. 3.

${ }^{2}$ See Dorothy Limouze, Aegidius Sadeler (ca. 1570-1629): Drawings, Prints, and Art History, (PhD diss., Princeton University, 1990), 357-58; and R. J. W. Evans et al., The Stylish Image: Printmak- 
ers to the Court of Rudolf II, exh. cat. (Edinburgh, National Gallery of Scotland, 1991), 51, no. 38, ill. between pp. 21 and 22; and Isabelle de Ramaix, Aegidius II Sadeler, vol. 72, part 2 (suppl.) of The Illustrated Bartsch (New York, 1998), 312-15, no. 7201.422.

${ }^{3}$ For more on the drawings of Van den Bossche, see Matthijs Ilsink, "The Drawings of Philips van den Bossche", Master Drawings 44 (2006): 333-53, no. 3 (with further references). On December 5, 2006, another drawing with an attribution to Philips van den Bossche was sold at Christie's London (Master Drawings from the Oppé Collection, no. 93).

${ }^{4}$ Thea Vignau-Wilberg, In Europa zu Hause: Niederländer in München um 1600, exh. cat. (Munich, Staatliche Graphische Sammlung, 2005).

${ }^{5}$ Heinrich Modern, "Eine Landschaft von Philip van den Bossche," 50-53.

${ }^{6}$ Paulus van Vianen, for example, earned 20 guilders per month (see Gerszi 1982, 12; and Ter Molen 1984, 23 n. 274). Pieter Stevens earned 8 guilders per month (see Zwollo 1968, 124), and Giuseppe Arcimboldo (ca. 1527-1593), 20 guilders (see Francine-Claire Legrand and Félix Sluys, Arcimboldo et les arcimboldesques [Paris, 1955], 35). Joseph Heintz the Elder (1564-1609), Hans von Aachen (1552-1615), and Bartholomaeus Spranger (1546-1611) -- the best paid artists at Rudolf's court -- all started on a monthly allowance of 15 guilders, an amount that was later raised to 45 guilders (see Thomas DaCosta Kaufmann, The School of Prague: Painting at the Court of Rudolf II [Chicago, 1988], 133 and 249).

${ }^{7}$ R. Bauer and H. Haupt, "Das Kunstkammerinventar Kaiser Rudolfs II. 1607-1611," Jahrbuch der Kunsthistorischen Sammlungen in Wien 72 (1976): 35-36, nos. 618 and 632.

${ }^{8}$ R. Bauer and H. Haupt, "Das Kunstkammerinventar Kaiser Rudolfs II. 1607-1611,“36, nos. 633-34.

${ }^{9}$ London, British Museum, inv. 1852-3-27.12, ebony case, wax, cloth, silk needlework, brass ornamentation, small tables of lapis lazuli (painted with oils), ivory, $62.3 \times 33.3 \times 13 \mathrm{~cm}$. ${ }^{10}$ See Koenraad Jonckheere, Willem Key (1516-1568): Portrait of a Humanist Painter; with an Appendix to the Oeuvre of Adriaen Thomasz. Key (Turnhout, 2011), 163-76, cat. 85; M. J. Friedländer, Early Netherlandish Painting, vol. 7 (Leiden and Brussels, 1971), 61, cat. 20, pl. 15 (it is believed the painting was begun by Quinten Metsys and finished by Willem Key). See also R. van der Heiden, Die Alte Pinakothek: Sammlungsgeschichte, Bau und Bilder (Munich, 1998), 28. A painted copy of the supposed prototype by Metsys is in Antwerp, Koninklijk Museum voor Schone Kunsten. See E. Vandamme, Catalogus schilderkunst oude meesters (Antwerp, 1988), 250, cat. 565. Given the numerous copies of the painting, it apparently remained a popular compositional formula during the sixteenth and seventeenth centuries. Painted copies are, for instance, in the church of St. Wandrille (Normandy) and in Bergen (Norway), Kunstsamlingene Bergen Billedgalleri (photos at the RKD, The Hague). See Jonckheere, Willem Key, cats. A86, A87, A107, and A108. A wax image after the painting by Allessandro Abondio is mentioned by D. Freedberg, The Power of Images (Chicago and London, 1989), 121. From 1635 on this image served as a Gnadenbild of the Congregatio Minor of the Munich Jesuits. Since 1945 Abondio's statue has disappeared, but a late seventeenth-century engraving after the image still survives. See P. Steiner, Altmünchner Gnadenstätten: Wallfahrt und Volksfrömmigkeit im kurfürstlichen München (Munich and Zurich, 1977), 47-48.

${ }^{11}$ E. Fucíková et al., Rudolf II and Prague: The Court and the City, exh. cat. (Prague and London, 1997), cat. II.131.

${ }^{12}$ R. Bauer and H. Haupt "Das Kunskammerinventar Kaiser Rudolfs II," 106-8.

${ }^{13}$ In the course of investigating the work some technical research was carried out with great 
generosity by Dr. Ineke Joosten at the former Instituut Collectie Nederland (ICN) nowadays Cultural Heritage Agency of the Netherlands (RCE) in Amsterdam on July 31, 2007. The chemical components of the metallic threads were analyzed in three places in a non-destructive way with X-ray fluorescence (XRF TRACeR III_V, Bruker, $40 \mathrm{KeV}, 2,2,2 \mathrm{~mA}$ ). Subsequently two samples of the metallic threads have been analyzed with an energy dispersive X-ray detector (EDX Vantage, ThermoNoran. SEM, JSM5910LV. The accelerating voltage was $20 \mathrm{keV}$. Analysis was carried out in low vacuum (26-41 Pa), while connected to a scanning electron microscope (SEM). XRF analysis shows that the metallic threads consist mainly of silver $(\mathrm{Ag})$ with trace of copper $(\mathrm{Cu})$ and gold $(\mathrm{Au})$. The SEM images showed that both metallic thread samples are flat, indicating that the threads were cut from silver strips gilded on one side. The thread of the sample indicated in fig. 3 with the number 1 is $50-60 \mu \mathrm{m}$ thick while the sample with number 2 is $10-15 \mu \mathrm{m}$ thick. ${ }^{14}$ For the history of manufacturing gilded silver strips, see M. Járó: “The Manufacturing Techniques of Metallic Threads: History from the Beginnings of Their Use up to the 20th Century, Based on Scientific Investigations," in Metaaldraad: Textiel op de wand, ed. A. J. de Graaf (Amsterdam, 2000),5-22; M. Járó, "Manufacturing Technique of Gold Threads and Their Imitations of Museum Textiles - Chronology of the Preparation of Metallic Threads: Results of the Scientific Investigations," special issue, Yearbook of the Textile Museum (Budapest) 8 ((1995): 31-49.

${ }^{15}$ The section "Vonn Seiden mit der Nadel Geneite Gemehl und Tafelein" in the imperial inventories actually points to the idea of considering needleworks like this to be paintings sewn in silk. See note 6.

${ }^{16}$ T. Stam, "Het goudborduren in de late middeleeuwen," in Metaaldraad. Textiel op de wand, ed. A. J. de Graaf (Amsterdam, 2000), 47-60.

${ }^{17}$ The varnish might be one of the main reasons for the survival of the needlework in the first place. The varnish was unevenly applied and was probably done to consolidate loose parts.

${ }^{18}$ The document is made of paper and written with brown ink, presumably iron gall ink. The brownish coating on top of the document is presumably an animal glue layer, which has darkened with time.

${ }^{19}$ Unfortunately, the name of the scribe remains unclear, although in line two a name seems to be written of a certain Arnoldt Kempes. However, this is difficult to decipher.

${ }^{20}$ Inquiries at the Niedersächsisches Landesarchiv - Staatsarchiv Wolfenbüttel in Wolfenbüttel have so far not led to anything. In a letter of August 1, 2005, Dr. Ulrich Schwarz informed us that accounts of criminal procedures from the beginning of the seventeenth century are almost absent in Wolfenbüttel.

${ }^{21}$ In the same way bookbinders used old paper to reinforce and fill the covers of a book.

22 "A little panel by Philip van den Bossche, embroiderer, depicting Our Lady and Joseph in a little landscape, lies in a limewood box, made of silk with the needle."

${ }^{23}$ The transcription of the text was done by Dr. Bert Thissen from the Stadtarchiv Kleve. For this we are much obliged to him. The passage where mention is made of Philips van den Bossche has been marked.

\section{Bibliography}

Bauer, R., and H. Haupt. “Das Kunstkammerinventar Kaiser Rudolfs II. 1607-1611." Jahrbuch der Kunsthistorischen Sammlungen in Wien 72 (1976): 35-36, 106-8. 
Evans, R. J. W., et al. The Stylish Image: Printmakers to the Court of Rudolf II. Exh. cat. Edinburgh, National Gallery of Scotland, 1991.

Freedberg, D. The Power of Images. Chicago and London, 1989.

Friedländer, M. J. Early Netherlandish Painting, vol. 7. Leiden and Brussels, 1971.

Fucíková, E., et al.. Rudolf II and Prague: The Court and the City. Exh. cat. Prague and London, 1997.

Heiden, R. van der. Die Alte Pinakothek: Sammlungsgeschichte, Bau und Bilder, vol. 28. Munich, 1998.

Ilsink, Matthijs. “The Drawings of Philips van den Bossche.” Master Drawings 44 (2006): 333-53.

Gerszi, Teréz. Paulus van Vianen: Die Handzeichnungen. Hannau, 1982.

Járó, M. "Manufacturing Technique of Gold Threads and Their Imitations of Museum Textiles - Chronology of the Preparation of Metallic Threads: Results of the Scientific Investigations." Special issue. Yearbook of the Textile Museum (Budapest) 8 (1995): 31-49.

Járó, M. “The Manufacturing Techniques of Metallic Threads: History from the Beginnings of Their Use up to the 20th century, Based on Scientific Investigations." In Metaaldraad: Textiel op de wand, edited by A. J. de Graaf, 5-22. Amsterdam, 2000.

Jonckheere, Koenraad. Willem Key (1516-1568): Portrait of a Humanist Painter; with an Appendix to the Oeuvre of Adriaen Thomasz. Turnhout, 2011.

Kaufmann, Thomas DaCosta. The School of Prague: Painting at the Court of Rudolf II. Chicago, 1988.

Legrand, Francine-Claire, and Félix Sluys. Arcimboldo et les arcimboldesques. Paris, 1955.

Limouze, Dorothy. “Aegidius Sadeler (ca. 1570-1629): Drawings, Prints, and Art History." PhD diss., Princeton University, 1990.

Modern, Heinrich. "Eine Landschaft von Philip van den Bossche." Mitteilungen der Gesellschaft für Vervielfältigende Kunst 11(1902): 50-53.

Ramaix, Isabelle de. Aegidius II Sadeler, vol. 72, part 2 (suppl.) of The Illustrated Bartsch. New York, 1998.

Rollová, Anna. "Philips van den Bossche."In Saur Allgemeines Künstler-Lexikon, 13:203. Munich and Leipzig, 1996. 
Stam, T. "Hetgoudborduren in de late middeleeuwen." In Metaaldraad: Textiel op de wand, edited by A. J. de Graaf, 47-60. Amsterdam, 2000.

Steiner, P. Altmünchner Gnadenstätten: Wallfahrt und Volksfrömmigkeit im kurfürstlichen München. Munich and Zurich, 1977.

Ter Molen, Johannes Rein. Van Vianen, een Utrechtse familie van zilversmeden met een internationale faam. 2 vols., Dissertation, Leiden University, 1984.

Vandamme, E. Catalogus schilderkunst oude meesters. Antwerp, 1988.

Vignau-Wilberg, Thea. In Europa zu Hause: Niederländer in München um 1600. Exh. cat. Munich, Staatliche Graphische Sammlung, 2005.

Zwollo, An. "Pieter Stevens, ein vergessener Maler des rudolfinischen Kreises." Jahrbuch der Kunsthistorischen Sammlungen in Wien, n.s. 28, 64 (1968): 119-80.

Recommended Citation:

Matthijs Ilsink and Monica Marchesi, "A needlework by Philips van den Bossche (fl. 1604-1615), " JHNA 5:1 (Winter 2013), D0I: 10.5092/jhna.2013.5.1.2 